\title{
Tata laksana Dermatitis Atopik pada Anak serta Pencegahan Terjadinya Asma di Kemudian Hari
}

\author{
Zakiudin Munasir
}

\begin{abstract}
Konsep allergic march saat ini banyak dipakai dalam pencegahan dini timbulnya penyakit alergi pada anak yang lahir dari keluarga atopik. Gejala alergi yang paling sering pada bayi usia dini adalah alergi makanan dengan manifestasi dermatitis atopik. Beberapa jenis makanan yang mencetuskan dermatitis atopik antara lain susu sapi, telur, ikan laut, kacang tanah, tomat, jeruk dan coklat. Diet eliminasi makanan alergen utama pada ibu menyusui dapat mencegah timbulnya penyakit alergi di kemudian hari pada bayi yang disusui. Penanganan pasien dermatitis atopik relatif sulit. Walaupun demikian, dengan tata laksana yang adekuat dengan kerjasama yang baik antara dokter, pasien dan keluarganya kelainan ini dapat diatasi. Secara garis besar, pengobatan dermatitis atopik meliputi penghindaran bahan iritan, faktor pencetus, mengatasi rasa gatal dan kekeringan kulit serta mengatasi reaksi peradangan dan infeksi sekunder. Pengobatan pencegahan dini dengan menggunakan setirisin pada anak dengan dermatitis atopik dilaporkan dapat menurunkan risiko terjadinya asma di kemudian hari.
\end{abstract}

Kata kunci: allergic march, dermatitis atopik, alergi makanan, asma bronkial, setirizin.

4

ermatitis pada anak merupakan penyakit kronik berulang yang dapat menimbulkan frustasi baik bagi pasien, orang tua maupun dokter yang menanganinya. Walaupun demikian, dengan tatalaksana yang adekuat kelainan ini dapat diatasi. Permasalahan yang sering dihadapi pada anak yang menderita dermatitis atopik adalah rasa gatal yang menyebabkan anak rewel, kelainan kulit yang menimbulkan rasa rendah diri pada anak yang lebih besar serta menghindar berbagai jenis makanan alergen yang dapat menimbulkan gangguan gizi yang akhirnya secara keseluruhan menyebabkan gangguan tumbuh kembang anak. Oleh karena itu, prinsip pengobatan dermatitis atopik adalah menghindari bahan iritan dan faktor pencetus, mengatasi rasa gatal dan kekeringan kulit serta mengatasi reaksi peradangan dan infeksi sekunder. Pengobatan dermatitis atopik harus

\footnotetext{
Alamat korespondensi:

Dr. Zakiudin Munasir, Sp.A(K).

Subbagian Alergi Imunologi Bagian Ilmu Kesehatan Anak FKUI-RSCM.

Jl. Salemba No. 6, Jakarta 10430.

Telpon 3161144. Fax. 3907743.
}

disesuaikan dengan keadaan pasien, apakah akut atau kronik.

Berbagai studi menunjukkan hubungan yang erat antara berbagai jenis penyakit atopi antara satu dengan lainnya yang lainnya yang dikenal dengan konsep allergy march atau road to allergy. Allergy march merupakan perjalanan penyakit alergi yang alamiah yang tidak dikontrol. Ekspresi penyakit alergi akan berubah sesuai dengan usia. Dengan tatalaksana serta tindakan pencegahan yang baik pada pasien dermatitis atopik diharapkan dapat mencegah terjadinya asma di kemudian hari.

\section{Identifikasi dan eliminasi faktor pencetus}

Sebelum diberikan terapi medikamentosa, penentuan faktor pencetus serta menghindarinya merupakan salah satu faktor yang penting dalam keberhasilan pengobatan dermatitis atopik. Peranan berbagai faktor pencetus seperti alergen udara atau alergen makanan telah banyak dibuktikan pada berbagai penelitian. 


\section{Alergen makanan}

Beberapa penelitian membuktikan, pada kasus defsiensi imun primer mudah terjadi peningkatan absorpsi alergen makanan serta peningkatan kejadian penyakit atopik ${ }^{1}$. Hal ini menunjukkan bahwa pada bayi dan anak yang menderita atopik terutama dermatitis atopik, ditemukan defisiensi imun ringan yang terkadang bersifat sementara; yang sering ditemukan adalah defisiensi imunoglobulin A ( IgA), komplemen serta sel limfosit T. Pada beberapa gangguan saluran cerna terjadi absorpsi sejumlah makromolekul makanan alergen yang dapat merangsang sintesis IgE spesifik. Pada bayi baru lahir terdapat defisiensi imun fisiologis terutama IgA sekretorik serta permeabilitas mukosa usus yang tinggi terhadap makromolekul makanan. Penyakit gastroenteritis juga mempunyai peran dalam peningkatan sensitisasi terhadap makanan.

Beberapa studi menunjukkan bahwa diet eliminasi yang ketat terhadap alergen makanan utama dapat mengurangi terjadinya dermatitis atopik pada bayi dengan risiko atopik tinggi. Diet eliminasi pada ibu menyusui dapat mencegah terjadinya penyakit atopik pada bayi yang disusui di kemudian hari ${ }^{2}$. Penundaan pemberian makanan padat (sampai 6 bulan) dilaporkan dapat menunda terjadinya dermatitis atopik ${ }^{3}$. Demikian juga pemberian ASI eksklusif (3-6 bulan) dapat mencegah terjadinya penyakit atopik ${ }^{4}$. Walaupun demikian, peneliti lain membuktikan sebaliknya yaitu penundaan pengenalan makanan hiperalergenik justru akan meningkatkan angka kejadian atopik di kemudian hari karena tidak ada stimulasi sel limfosit $\mathrm{T}$ penekan (Ts) yang mengontrol produksi IgE oleh sel limfosit $\mathrm{B}^{5}$. Beberapa jenis makanan yang sering menimbulkan dermatitis pada kasus atopik antara lain susu sapi, telur, ikan laut, kacang tanah, tomat, jeruk dan coklat ${ }^{6}$.

\section{Diet eliminasi}

Samson dan Caskill ${ }^{7}$ membuktikan, dengan diet eliminasi makanan alergen selama 3 tahun selain menunjukkan perbaikan klinis juga didapatkan penurunan kadar IgE secara bermakna. Hasil penelitian ini menunjukkan bahwa diet eliminasi makanan pencetus merupakan tatalaksana yang penting pada kasus dermatitis atopik. Walaupun demikian diet eliminasi makanan harus tetap memperhatikan kebutuhan nutrisi anak yang sedang tumbuh yaitu mengganti dengan makanan lain yang mempunyai nilai gizi yang setara. Diet eliminasi makanan pencetus berdasarkan uji DBPCFC (double blind placebo control food challenge) sebenarnya sangat ideal tetapi kurang praktis. Menurut para ahli diet eliminasi cukup berdasarkan uji kulit disertai anamnesis yang cermat. Diet eliminasi biasanya dilakukan selama 3-6 minggu, bila terjadi perbaikan klinis dilakukan pengenalan kembali dengan makanan tersebut secara bertahap.

\section{Alergen udara}

Penghindaran alergen udara pencetus dermatitis atopik terbukti dapat mengontrol gejala dermatitis atopik. Dengan membersihkan tungau dari lingkungan pasien ternyata dapat memperbaiki gejala klinis tanpa pengobatan lain. Bila pasien tersebut kembali ke lingkungan semula, dalam waktu 1-2 hari dapat terjadi eksaserbasi penyakitnya.

\section{Bahan iritan}

Kulit pasien dermatitis atopik biasanya kering, sensitif serta mudah mengalami iritasi. Untuk mencegah iritasi, penggunaan sabun dan pembersih kulit yang lain harus dikurangi. Sabun yang digunakan harus mempunyai $\mathrm{pH}$ netral, sebaiknya menggunakan pembersih kulit yang tidak mengandung bahan sabun. Sisa deterjen pada pakaian juga dapat menimbulkan iritasi. Oleh karena itu setiap mencuci pakaian harus dilakukan pembilasan sampai benar-benar bersih. Pengeluaran keringat karena suhu, emosi atau lingkungan sekitar dapat menimbulkan rasa gatal. Aktivitas fisik harus dikurangi untuk mencegah pengeluaran keringat yang berlebihan. Suhu dan kelembaban lingkungan harus optimal (suhu $33-41^{0}$ Celcius dengan kelembaban 45$55 \%)^{8}$.

Pakaian jangan terlalu ketat, bahan pakaian harus disesuaikan dengan keadaan kulit, misalnya jangan menggunakan bahan wol bagi yang sensitif terhadap wol. Berenang merupakan olah raga yang dianjurkan, akan tetapi harus segera dibilas dengan air bersih karena kolam renang sering mengandung kaporit dan harus segera menggunakan pelembab atau pembalutan kulit yang sakit. 


\section{Mencegah kekeringan kulit}

Hidrasi kulit baik dilakukan pada berbagai stadium penyakit. Untuk mengatasi kekeringan kulit dilakukan dengan membasahi kulit dengan air dan dibalut dengan pembalut hidrofobik supaya tidak menyerap air tersebut. Tindakan ini dapat dilakukan dengan berendam atau mandi selama 15-20 menit. Sebaiknya jangan mandi dengan air panas karena sering merangsang timbulnya gatal. Setelah mandi kulit dikeringkan dengan handuk lembut dan segera diberikan terapi topikal. Bila kulit tidak segera dibalut dalam 3-5 menit mudah terjadi kekeringan. Dengan cara ini dapat meningkatkan penetrasi obat topikal bila segera diberikan. Penggunaan pembalut basah bermanfaat untuk hidrasi selanjutnya dan dapat meningkatkan penetrasi obat serta pendinginan kulit - Pembalutan lebih praktis dilakukan pada saat tidur. Mandi dan kompres juga efektif untuk menghilangkan krusta serta mengurangi eksudasi. Kompres dengan larutan astringent dan antiseptik hanya boleh dilakukan 2 sampai 3 kali sehari karena dapat menyebabkan kekeringan yang menimbulkan gatal serta kulit pecahpecah.

Pelembab tersedia dalam bentuk lotion atau krim; lotion mengandung lebih banyak air dibanding krim tetapi lebih mudah menguap. Beberapa jenis pelembab mengandung air dan minyak. Pelembab ini dapat digunakan 3 sampai 4 kali sehari termasuk segera setelah mandi. Pembalut kering hanya efektif bila digunakan setelah hidrasi kulit untuk mencegah penguapan karena pembalut tidak mengandung air.

\section{Medikamentosa}

Pengobatan medikamentosa terutama ditujukan untuk mengatasi rasa gatal, reaksi peradangan, infeksi sekunder serta perbaikan sistim kekebalan tubuh.

\section{Mengatasi rasa gatal}

Rasa gatal pada dermatitis atopik merupakan gejala utama dan sangat mengganggu. Goresan akibat garukan dapat dikurangi dengan memotong kuku, menggunakan sarung tangan serta obat antihistamin. Manfaat antihistamin untuk mengatasi rasa gatal pada dermatitis atopik masih dalam perdebatan; akan tetapi beberapa peneliti membuktikan penggunaan hidroksisin, loratadin serta setirisin sangat bermanfaat mengatasi rasa gatal pada dermatitis atopik. Selain merupakan antagonist $\mathrm{H} 1$, obat-obatan ini juga mengahambat reaksi tipe I fase lambat dan PAF (platelets activating factor) ${ }^{9}$ serta menghambat neutrofil, eosinofil dan basofil ke tempat kulit yang mengalami reaksi alergi. ${ }^{10}$ Penggunaan antihistamin topikal serta anestetik lokal sebaiknya dihindari karena dapat menginduksi reaksi hipersensitivitas sistemik. Sedatif kadang diperlukan untuk mencegah garukan pada malam hari.

\section{Mengatasi reaksi peradangan}

Beberapa obat digunakan untuk mengatasi reaksi peradangan yaitu kortikosteroid (lokal atau sistemik) serta tar. Kortikosteroid topikal sering diperlukan pada saat eksaserbasi akut dermatitis atopik. Kortikosteroid topikal mempunyai efek antiinflamasi, antipruritus serta vasokonstriktor. Kortikosteroid fluorinasi dan esterifikasi mempunyai potensi yang lebih kuat dibandingkan dengan yang non- fluorinasi dan non esterifikasi (Tabel 1).

Tabel 1. Potensi relatif berbagai kortikosteroid topikal

\begin{tabular}{|c|c|}
\hline Kelas & Nama generik \\
\hline \multicolumn{2}{|c|}{ Potensi paling rendah \% } \\
\hline 0,1 & Deksametason \\
\hline 1 & Hidrokortison \\
\hline \multicolumn{2}{|c|}{ Potensi rendah \% } \\
\hline 0,01 & Betametason valerat \\
\hline 0,05 & Desonid \\
\hline 0,025 & Triamsinolon asetonid \\
\hline \multicolumn{2}{|c|}{ Potensi menengah \% } \\
\hline 0,1 & Betametason valerat \\
\hline 0,05 & Desoksimetason \\
\hline 0,2 & Hidrokortison valerat \\
\hline 0,025 & Halsinonid \\
\hline 0,1 & Triamsinolon asetonid \\
\hline \multicolumn{2}{|c|}{ Potensi tinggi \% } \\
\hline 0,1 & Amsinonid \\
\hline 0,05 & Betametason dipropionat \\
\hline 0,25 & Desoksimetason \\
\hline 0,2 & Flusinolon \\
\hline 0,05 & Flusinonid \\
\hline \multicolumn{2}{|c|}{ Potensi sangat tinggi \% } \\
\hline 0,05 & Betametason dipropionat \\
\hline 0,05 & Klobetasol propionat \\
\hline 0,05 & Halobetasol \\
\hline
\end{tabular}

Catatan: Lotion dan krim generik kadang - kadang masih mengandung bahan alergen. Dikutip dari Addinoff AD. dkk. ${ }^{8}$ dengan modifikasi 
Pemilihan kortikosteroid topikal tergantung lokasi dan luasnya lesi. Sebaiknya digunakan potensi serendah mungkin yang masih efektif. Bentuk krim lebih mudah penggunaannya tetapi mudah menimbulkan kekeringan. Bentuk salep mempunyai efek melindungi kulit dari kekeringan, tetapi dapat meningkatkan rasa gatal serta dapat menimbulkan folikulitis. Oleh karena itu bentuk krim cocok untuk lingkungan yang lembab sedangkan lotion dan spray lebih cocok untuk kulit kepala atau kulit berambut. Penggunaan kortikosteroid topikal sebaiknya tidak lebih dari 2 kali sehari karena tidak meningkatkan efikasi malah menambah biaya pengobatan. ${ }^{8}$ Pada daerah kulit yang tipis seperti daerah muka, leher, ketiak dan selangkangan sebaiknya tidak digunakan kortikosteroid topikal potensi sedang atau tinggi kecuali digunakan dalam jangka pendek dengan pengawasan yang ketat. Efek samping penggunaan kortikosteroid topikal tersering antara lain, katarak bila digunakan di daerah periorbital, atropi kulit, hipopigmentasi, jerawat dan terkadang efek sistemik. Dapat pula terjadi infeksi sekunder oleh jamur.

Pemberian kortikosteroid sistemik biasanya tidak dianjurkan walaupun dapat menunjukkan penyembuhan yang cepat. Terkadang didapatkan efek rebound pada penghentian pengobatan disamping efek samping lainnya. Walupun demikian hasil studi terakhir melaporkan hasil yang memuaskan dari pengobatan kortikosteroid sistemik dosis rendah secara alternatif pada dermatitis atopik yang refrakter terhadap pengobatan kortikosteroid topikal potensi tinggi ${ }^{11}$.

Tar serta ekstrak crude cool tar telah digunakan bertahun-tahun dan sering dianjurkan untuk mengurangi penggunaan kortikosteroid topikal pada dermatitis atopik. Liquor carbonis detergents (LCD) 2,5\% dan 5\% dalam aquaphor banyak digunakan dalam sediaan kosmetik dengan iritasi minimal. Walaupun preparat tar ini banyak digunakan pada produk kosmetik, kandungan alkohol di dalamnya dapat menimbulkan rasa terbakar serta iritasi pada daerah dermatitis. Efek samping tar antara lain folikulitis, fotosensitisasi serta dermatitis kontak.

\section{Pengobatan infeksi sekunder}

Dermatitis akut maupun kronis yang tidak terkontrol sering disertai infeksi sekunder yang memerlukan terapi antibiotik sistemik. Bila tidak ditangani dengan baik akan memperburuk gejala dermatitis yang telah ada.
Penyebab infeksi tersering adalah Staphylococcus aureus yang sering kali telah resisten terhadap penisilin. Untuk itu perlu dilakukan biakan dan uji resistensi untuk menentukan antibiotik yang sesuai. Sebaiknya diberikan antibiotik dosis tinggi untuk mencapai kadar yang cukup pada kulit yang terkena. Pilihan pertama adalah sefaleksin dan eritromisin. Pilihan lain adalah klindamisin dan dikloksasilin atau kombinasi dikloksasilin dan rifampisin'. Pengobatan sebaiknya diteruskan 2 sampai 3 minggu.

Pembersih antiseptik tidak dianjurkan karena dapat terjadi iritasi. Pengobatan dengan antibiotik topikal biasanya tidak efektif bahkan dapat menimbulkan sensitisasi. Beberapa ahli mendapatkan hasil yang baik dengan menggunakan mupirosin, namun harganya relatif mahal. Bila pengobatan dengan antibiotik gagal perlu dipikirkan adanya infeksi Herpes simplex. Keadaan yang ringan dapat diobati dengan asiklovir topikal sedangkan herpes yang luas atau mengancam mata dapat diberikan asiklovir intravena. Pengobatan dengan antimikotik seperti krim imidasol atau griseovulvin oral selama satu bulan diberikan pada infeksi jamur dermatofit. Infeksi Pityrosporum ovale dapat diobati dengan klotrimasol.

\section{Perbaikan sistim imun}

Kasus dermatitis atopik sering menunjukkan gangguan regulasi sistim imun, oleh karena itu dapat diberikan pengobatan untuk memperbaiki sistim imun. Biasanya pengobatan ini merupakan alternatif bila dengan pengobatan di atas mengalami kegagalan.

\section{Imunoterapi allergen}

Imunoterapi/desensitisasi pada dermatitis atopik ditujukan terhadap alergen udara. Cara pengobatan ini sampai sekarang masih diperdebatkan apakah efektif. Beberapa peneliti melaporkan hasil yang baik, sedangkan peneliti lain mendapatkan hasil yang mengecewakan bahkan dapat memperburuk gejala dermatitisnya? Untuk ini diperlukan data yang lebih banyak dengan melakukan penelitian yang menggunakan kontrol .

\section{Interferon gamma}

Pada kasus dermatitis atopik didapatkan penurunan kapasitas pembentukan interferon gamma oleh sel mononuklear ${ }^{12}$. Interferon gamma merupakan sitokin 
penghambat interleukin-4 yang merangsang produksi IgE serta menghambat sel limfosit $\mathrm{Th}_{2}$. Uji klinis pemberian interferon gama dengan menggunakan plasebo menunjukkan perbaikan klinis yang bermakna disertai penurunan hitung eosinofil total dan sintesis $\operatorname{IgE}$ invitro $^{13}$.

\section{Timopentin}

Timopentin merupakan pentapeptida sintetik yang dapat meningkatkan diferensiasi timosit dan fungsi limfosit $T$ tetapi memerlukan waktu yang agak lama. Uji klinis dengan kontrol plasebo selama 6 minggu baru menunjukkan perbaikan pruritus dan eritem secara bermakna ${ }^{14}$.

\section{Siklosporin}

Siklosporin dapat digunakan untuk menekan produksi sitokin. Pada uji klinis dengan kontrol plasebo selama 8 minggu didapatkan perbaikan klinis yang bermakna ${ }^{15}$. Oleh karena adanya efek hepatotoksik dan imunosupresif, pengobatan ini tidak disukai kecuali pada dermatitis atopik yang refrakter terhadap pengobatan.

\section{Fototerapi}

Pemberian sinar ultraviolet dapat bermanfaat pada dermatitis kronik dan rekalsitrans. Sebaliknya, sinar matahari yang berlebihan atau udara yang panas dan lembab dapat menimbulkan rasa gatal. Penggunaan sinar UVA (ultraviolet) atau psoralen phototherapy (PUVA) dapat menyebabkan remisi pada dermatitis yang berat ${ }^{16}$. Keadaan ini mungkin disebabkan efek supresi terhadap sel Langerhans atau sel mast kulit. Terapi sinar ini juga dapat meningkatkan respons tehadap terapi lain yang diberikan; karena respons terapi lambat, biaya mahal serta risiko terjadinya kanker maka penggunaan terapi sinar ini sangat terbatas.

\section{Psikoterapi}

Pasien dermatitis atopik biasanya menunjukkan gejala seperti pada penyakit kronik lain yaitu gangguan emosi yang juga diderita oleh orang tua/keluarganya. Dermatitis atopik adalah suatu penyakit yang tampak oleh orang lain yang menyebabkan rasa rendah diri cenderung depresi dan sangat mengganggu pasien.
Pasien maupun orangtuanya sering merasa kesal karena penyakitnya tidak kunjung sembuh, demikian juga dokter yang menanganinya sering merasa frustasi. Oleh karena, itu perbaikan emosi dengan psikoterapi merupakan penunjang yang penting dalam pengobatan dermatitis atopik. Psikoterapi tidak harus dilakukan oleh dokter yang mengobati tetapi dapat dilakukan oleh tenaga kesehatan/psychotherapist. Pemberian psikoterapi secara kelompok lebih banyak menunjukkan hasil .

\section{Pencegahan terjadinya asma di kemudian hari}

Beberapa penelitian menunjukkan bahwa pada anak dengan dermatitis atopik walaupun tidak menunjukkan gejala asma didapat gejala hiperreaktivitas bronkus nonspesifik sehingga mempunyai risiko terjadinya asma di kemudian hari ${ }^{17,18}$. Dengan tatalaksana yang baik maka terjadinya sensitisasi terhadap reaksi alergi akan ditekan sehingga manifestasi terjadinya ekspresi penyakit alergi yang lain misalnya asma di kemudian hari dapat dicegah. Laporan mutakhir menunjukkan bahwa dengan modus pengobatan pencegahan yang dilakukan melalui pengobatan dini anak atopi dapat mencegah timbulnya asma bronkial di kemudian hari. Konsep dasar pengobatan dini ialah manifestasi klinis asma kemungkinan dapat dicegah atau dihentikan dengan intervensi medis sebelum penyakit tersebut muncul atau meminimalkan gejala yang timbul. Oleh karena itu sasaran pengobatan pencegahan ini adalah anak dengan gejala dermatitis atopi yang belum menujukkan gejala wheezing (mengi). Penelitian ini yang dikenal dengan nama ETAC (early treatment of the atopic child) merupakan suatu penelitian uji klinis buta ganda secara acak dengan kontrol plasebo yang dilakukan di 12 negara Eropa dan Kanada dengan tujuan untuk melihat apakah pemberian setirisin pada kasus dermatitis atopi dengan riwayat atopi keluarga dapat menurunkan insidens asma secara bermakna. Dari laporan awal penelitian ETAC tersebut dapat disimpulkan bahwa penggunaan setirisin jangka panjang dengan dosis $0,25 \mathrm{mg}$ perKg perBB dua kali sehari selama 18 bulan, menurunkan probabilitas timbulnya asma sebesar $50 \%$ pada kelompok anak yang tersensitisasi oleh serbuk bunga dan tungau debu rumah. Selain itu penggunaan setirisin jangka panjang dapat membatasi kekerapan dan lama pemberian kortikosteroid pada anak yang menderita dermatitis atopik $^{19}$. 


\section{Daftar Pustaka}

1. Soothil JF. The atopic child. Dalam: Soothil JF, Hayward AH, Wood CBS, penyunting. Paediatric Immunology. Oxford: Blackwell Scientific Publications; 1982. h. 248-71.

2. Sigurs N, Hatterig G, Kjellman B. Maternal avoidance of eggs, cow's milk and fish during lactation: Effect on allergic manifestations, skin prick test, and spesific $\operatorname{IgE}$ antibodies, in children at age 4 years. Pediatrics 1992; 89:735-9.

3. Kajosaari M, Saarinen UM. Prophylaxis of atopic disease by six months total solid food elimination. Acta Paediatr Scand 1983; 73:411-4.

4. Mygind N. Essential Allergy. Oxford : Blackwell Scientific Publication Publications; 1986. h. 384-6

5. Lindfors A, Enockson E. Development of atopic disease after early administration of cow's milk formula, Allergy 1988; 43:11-6.

6. Hanifin JM. Atopic dermatitis in infant and childhood.Dalam : Hurtwitz S, penyunting.Pediatric Dermatology. Philadelphia: WB Saunders Company; 1991. h. 763-91.

7. Sampson HA, McCaskill CC. Food hypersensitivity and atopic dermatitis. Evaluation of 113 patients. J Pediatr 1985; 107:669-75.

8. Adinoff AD, Clark RAF. Atopic Dermatitis. Dalam : Bierman CW, Pearlman DS, Shapiro GG, Busse WW. Penyunting. Allergy, Asthma and Immunology from Infancy to Adulthood. Philadelphia : WB Saunders Company; 1996. h. 613-32.

9. Mitchell EB, Crow J, Chapman MD, et al. Basophils in allergen-induced patch test sites in atopic dermatitis. Lancet 1982; 1:127-30.

10. Charlesworth EN, Kagey-Sabotka A, Norman PS, et al.
Effect of cetirisine on mast cell-mediator release and cellular traffic during the cutaneus late-phase reaction. J Allergy Clin Immunol 1989; 83:905-12.

11. Sonenthal KR, Grammer LC, Patterson R. Do some patients with atopic dermatitis require long term oral steroid therapy? J Allergy Clin Immunol 1993; 91:971-73

12. Jujo K, Renz H, Abe J, Gelfand EW, Leung DYM. Decreased INFg and increased IL-4 in atopic dermatitis. J Allergy Clin Immunol 1992;90:323.

13. Boguniewicz M, Jaffe HS, Izu A, dkk. Recombinant gamma interferon therapy in treatment of patients with atopic dermatitis and elevated IgE levels. Am J Med 1990;88:365-70.

14. Leung DYM, Hirsh RL, Schneider L, Moody C, Takaoka $\mathrm{R}$, Li SH dkk. Thymopentin therapy reduces the clinical severity of atopic dermatitis. J Allergy Clin Immunol 1990; 85:927-33.

15. Sowden JM, Berth-Jones J, Ross JS, Motley RJ, Marks R, Finlay. Double blind, controlled, crossover study of cyclosporin in adults with severe refractory atopic dermatitis.Lancet 1991;338:137-40.

16. Altherton DJ, Cababott F, Glover MT, dkk. The role of psoralen chemotherapy (PUVA) in the treatment of severe atopic eczema in adolescence. Br J Dermatol 1988; 118:791-95.

17. Bjorksten B. The enviromental influence on childhood asthma. Allergy 1999; 54:17-23.

18. Bonini S, Denburg JA. The Role of Schock Organs in Influencing the Clinical Expression of Allergy. Allergy 1999; 54:3-6.

19. Wahn U. Allergic Factors associated with the development of asthma and the influence of cetirizine in a double-blind, randomized, placebp-controlled trial: First results of ETAC. Pediatr Allergy Immunol 1998; 9:116-124. 